\title{
Building the Corporate Reputation of Non-Traditional Export Firms in Ghana: Conceptualizing the Customers' Perspective
}

\author{
John Amankwaa ${ }^{1}$, Krishna Govender ${ }^{2}$ \\ ${ }^{1}$ School of Management, IT and Governance, University of KwaZulu-Natal, South Africa \\ ${ }^{2}$ Da Vinci Institute of Technology Management, South Africa \\ Email: govenderkrishna@gmail.com
}

\begin{abstract}
In the export trade, it is prudent to understand the customer and the customers' perception of the quality of the corporate reputation of non-traditional export (NTE) firms will make the NTE firms competitive. Many countries have launched diversification programmes to promote the NTE commodities. In Ghana, there are over 383 different NTE products, while about 3000 firms have registered with the Ghana Export Promotion Authority. In the past few years, however, some products from Ghana have faced a ban or threats of a ban from the European Union (the largest trading partner), as well as Ghana's Ministry of Food and Agriculture, for exporting less quality products. Hence, NTE firms in Ghana are facing a challenge of maintaining a good reputation, particularly, from the customers' perspective. In light of the above, this conceptual paper will draw from the extant literature on corporate reputation and propose a framework for building the corporate reputation for NTE firms in Ghana.
\end{abstract}

Keywords: Reputation, corporate reputation, export, non-traditional products

\section{Introduction}

Researchers (Ingenhoff, Buhmann, White, Zhang \& Kiousis, 2018) have suggested that an organization's crisis can do damage both to the organization's reputation and how the home country is perceived abroad. All manner of firms - small, medium and large; located in any part of the world - are in a strict competition, and reputation is becoming a key influencer of a firm's competitiveness. In general, corporate reputation is about "perception, opinions, and attitudes" or beliefs held by stakeholders of an organization and its products (Jung \& Seock, 2016). Such an opinion could be based on past experiences or the information or misinformation individuals have received on the company and its activities. In order to build a strong corporate reputation, the organization should interact well with its multitude of stakeholders and try to satisfy those (Matuleviciene \& Stravinskiene, 2015).

While the marketing literature acknowledges the immense role corporate reputation plays in enhancing a firm's performance (Jung \& Seock, 2016; Kanto, de Run, Md Isa, 2015), little is known on the reputation of small and young firms such as non-traditional export firms in least developed countries. Furthermore, many studies explore the corporate reputation of companies in the advanced economies including United States and Europe (Ali, Lynch, Melewar \& Jin, 2015) and in bigger firms (Gul, 2014).

The perception held by stakeholder groups is central in the corporate reputation research (Ali, Lynch, Melewar \& Jin, 2015) and the marketing literature describes the customer as the most important stakeholder of a company (Duygun, Mentes \& Kubas, 2014; Shamma \& Hassan, 2013), and that all actions a company takes must lead to satisfying the customer. According to Zavyalova, Pfarrer, Reger, and Hubbard (2016:255), reputation provides a firm with such advantages as "better access to resources, ability to employ high quality workers, and greater chances of financial success". In order to diversify the economy, governments such as that of Ghana have, over the past four decades, supported local export firms to enhance the export of non-traditional products. The export of non-traditional sector products has the potential for creating employment for the citizens, raising their levels of income and contributing significantly to the nation's foreign exchange earnings. In recent years, however, the export of non-traditional products has received threats of ban from the European Union as a result of the low quality of some agricultural products (Ghana News Digest, 2014). Hence, the non-traditional export 
firms in Ghana are facing a challenge of maintaining a good reputation, particularly, in the eyes of customers.

In the light of the above, this paper crafts a conceptual framework to evaluate the customers' perception of corporate reputation of the non-traditional export firms in Ghana.

\section{Background and Literature}

According to Christaensen and Devarajan (2013), for resource-poor countries such as Ghana, agriculture and services are the means to drive the growth of the economy and that the contributions of agriculture in such countries is about 2.5 percent points per year compared to one (1) percent in the fast-growing resource-rich countries. With the world fast becoming a global village, and several trade barriers removed, the government of Ghana has sought to promote export marketing as one of the diversification strategies. The Ghana's Import and Export Act 1995 (503) classifies the nation's export products into two, namely; traditional and non-traditional. Traditional exports are products which have a history of export production over a number of years, and have been consistent foreign exchange earners and include cocoa beans, timber logs and lumber, unprocessed gold and other minerals, electricity and crude oil. On the other hand, non-traditional exports are those goods which have little or no export history and which have yielded insignificant export earnings or have not been the country's principal sources of foreign exchange (Agyei-Sasu, Anaman \& Egyir, 2011).

\subsection{Ghana's Non-Traditional Export (NTE) Sector}

Since independence in 1957, the government of Ghana sought to diversify the nation's export base from over-reliance on traditional exports (unprocessed minerals, cocoa beans, timber logs and lumber and electricity), to non-traditional exports. Hence, the Ghana Export Promotion Agency (GEPA) was established in 1969 by NLCD 396, as an agency of the Ministry of Trade and Industry to develop and promote the nation's non-traditional export sector. The GEPA revealed that as of 2016, Ghana had over 383 different non-traditional export products categorized into four as follows:

a. Agricultural Products. These are horticultural products, fresh fruits, medicinal seeds and plants, and tropical flowers and vegetables.

b. Manufactured Products. These involve processed foods, such as canned tuna, cocoa and Sheabutter products, pharmaceuticals, electrical cables, and aluminum products.

c. Handicrafts. They involve woodcrafts, baskets, ornamentals such as beads, jewelry, and kente products.

d. Services. These focus on business process outsourcing, consultancy services, medical, tourism, and education.

The Non-Traditional Export (NTE) sector contributes significantly to Ghana's economy. For instance, the value of merchandise exports from Ghana (both traditional and non-traditional exports) in 2013 was US\$ 13752 million, representing 31.1 percent of the nation's Gross Domestic Product (GDP) (OseiAssibey, 2015). The NTE sector earned US\$ 2418.6 million in 2013, accounting for about 17.5 percent of the total export value for the year (2013). The NTE sector further provides employment opportunities to people in the primary sector to generate income and also helps move the farmers out of poverty (Agyei-Sasu et al., 2011). The NTE firms in Ghana are owned by private individuals and regulated by the Ghana Export Promotion Authority (GEPA) an agency under the nation's Ministry of Trade and Industry. Currently, there are over 3000 firms in the country that have registered with the GEPA to engage in exportation of non-traditional products (GEPA, 2015). While some of the firms produce and export own products, others simply buy products and prepare them for export. The firms have been categorized into seventeen product associations. The GEPA organizes workshops, forums, conferences and seminars for the owners/managers of the NTE firms, as well as trade fairs, exhibitions, trade missions and buyer-seller meetings for the export firms.

GEPA reports indicate that Ghana exports non-traditional products to more than 60 destinations around the world and the European Union (EU) market has been the largest destination for Ghana's non-traditional products over the past decade (2003 - 2013), accounting for 47 percent of all exports (Osei-Assibey, 2015). Netherlands, France, Germany and the United Kingdom are among the top 
trading partners; others were the United States, Italy, Spain, Belgium, Japan, Nigeria, Malaysia, Ukraine, Turkey, China, India and Portugal (Osei-Assibey, 2015). Ghana's non-traditional exports to the EU were predominantly primary products with little value added constituting 83 percent, while only nine percent of exports to the EU were in manufactured form (GEPA, 2016).

Nigeria has been the biggest market for Ghana's NTE products in the African /ECOWAS sub-region and the major products exported to Nigeria include spirits, liqueurs and alcohol products, cocoa chocolate, palm-kernel, plywood and veneer and aluminum products. The value of exports to Nigeria, however, fell from US\$ 393929 million in 2005 to US\$ 141098 million in 2013, declining more than 64 percent (Osei-Assibey, 2015). According to GEPA, the decline of exports to Nigeria was the result of Nigeria's ban on importation of over 150 products into that country.

\subsection{Corporate Reputation}

The NTE firms in Ghana are basically small and medium-sized firms and research shows that such (small and medium-sized) firms are more vulnerable and face reputation problems compared to the larger firms because they might not a good export history (Manjunatha \& Kumar, 2016; Nicolo, 2015). Several researchers have recommended that firms that seek to build a positive reputation must satisfy the expectations of their customers and the other stakeholders (Nicolo, 2015; Artopoulos, Friel \& Hallak, 2013).

In February 2014, some agricultural products from Ghana faced threats of being banned from the European Union (which is Ghana's largest market), because products did not conform to the required EU consumer standards (Ghana News Digest, 2014). In August 2014, Dr Ahmed Yakubu Alhassan, Ghana's Deputy Minister of Agriculture announced that the ministry had placed an embargo on exportation of vegetables from Ghana to the EU market for three months because they were unsafe (myjoyonline.com. 2014). The ban affected a number of stakeholders of the non-traditional export sector.

In particular, it negatively affects the employment and incomes of citizens in the agricultural sector, as well as the reputation of the export firms and the nation's image (Nicolo, 2015). Research shows that firms can experience negative reputation as a result of certain "controlled and uncontrolled factors" (Petkeviciene, 2014), but Sontaite-Petkeviciene (2014) posit that a damaged reputation can be corrected by appropriate discharge of the role of the Chief Executive Officer, the organizational activities and effective communication strategy of the company.

\section{The Research Problem}

The ability of firms to have a high reputation and become competitive in both local and global markets remains a challenge for NTE firms in Ghana. This is evident by the banning of certain products into the EU markets between 2012 - 2013, followed by a further ban from 2014 - 2017 (GEPA, 2017). The question is "How can NTE firms in Ghana build favorable corporate reputation to attract and retain customers?"

For the purpose of this study, corporate reputation is conceptualized as the customers' overall evaluation of a firm, based on their beliefs about the firm's product and service quality, being a good employer, its customer-orientation, social and environmental responsibility, and financial stability. These aspects will be briefly discussed and relationships will be proposed to develop a conceptual model to manage the corporate reputation of non-traditional export firms.

\subsection{Product Quality}

From the perspective of the customer, product quality is the degree to which satisfaction is met from a product or service, measured by a set of inherent signs (Suchanek et al., 2015). Kalita and Nath (2014) believe that the quality of a product is viewed from eight dimensions namely; performance, features, reliability, conformance, durability, serviceability, aesthetics, and perceived quality. High quality products enhance customer satisfaction, and that influences the growth and popularity of the company (Hidayat, Mahdaria, Linando \& Ishak, 2017; Evans \& Lindsay, 2014). Studies show that product quality has a relationship with corporate reputation. For instance, Fombrun et al. (2015) note that 
customers, like the other stakeholders, can be expected to develop perceptions of a company, based on the quality of its products; again, firms with high quality products will have better corporate reputation (Hidayat et al., 2017). On the other hand, companies with product-related problems can suffer productrecalls, exchanging of products, and negative word-of-mouth (Grunwald \& Hempelmann, 2010).

In light of the above, it is proposed that

$P$ 1: Product quality has positive relationship with customer-based corporate reputation.

\subsection{Employer Characteristics}

Good employer dimensionsevolve from the internal marketing concept which posits that employees are the internal customers of the firm and jobs are its internal products. To have satisfied customers, the firm must first have satisfied employees (Almacik, Almacik, Erat \& Akein, 2014; Wallace, Lings, Cameron \& Sheldon, 2014). Helm (2011) notes that a firm's conduct becomes manifest in the behavior of the employees who represent the firm and interact with the other stakeholders in order to satisfy customers. According to Walsh, Mitchell, Jackson and Beatty (2009), good employer dimension denotes the customers' perception about how a firm and its management treats its employees and pays attention to their interests; and customers' expectations that the firm has competent employees. This involves how well the firm treats people and how much attention is given to the needs of employees (Shahsavani \& Faryabi, 2013; Bartikowski \& Walsh, 2011).

The good employer concept suggests that a firm enjoys good reputation when it is perceived as a good place to work in the minds of existing and potential employees and the other stakeholders in the external market (Dabirian, Kietzmann \& Diba, 2016). Reputable firms are able to create a culture that provides a rewarding work experience for employees (Love \& Singh, 2011) and thus attract, recruit and retain qualified and experienced employees (Wallace et al., 2014). On the basis of the above, it is proposed that:

$P$ 2: The extent to which customers desire to become employees of NTE firms in Ghana positively influences the reputation of the firms.

\subsection{Customer Orientation}

Generally, customer orientation has been defined as having "sufficient understanding of one's target buyers to be able to create superior value for them continuously" (Frambach \& Ingenbleek, 2016). It is the customers' perceptions about the degree to which a firm and/or its employees obtain and use information from customers in order to provide goods and services that meet customer needs (Ziggers \& Henseler, 2016; Raie, Khadivi \& Khedaie, 2014). Researchers have observed that customer orientation can be developed at two levels - the firm itself and the employees (Maurya et al., 2015). At the firm level, Hanzaee and Mirvaisi (2011) suggest that management needs to collect information on each customer's demographics, psychographics, past transactions, media and distribution preferences". Ziggers and Henseler (2016) describe customer-oriented firms as those that place high priority on present and future customer needs and channel their abilities to sensing events and trends in the customer base and responds to that information.

At the individual level, researches have focused on the inter-personal contacts; mainly on the quality of the salesperson-customer relationship (Mokhtaran \& Komeilian, 2016; Maurya et al., 2015; Singh \& Koshy, 2012). Singh and Koshy (2012) relate customer orientation to "concern for others" - that is concern for oneself as well as for others. The main characteristics of this salesperson-customer relationship, according to Singh and Koshy (2012) are the desire to help customers make satisfactory purchasing decisions; helping customers assess their needs; offering products that will satisfy customers' needs; describing products accurately; adapting sales presentations to match customer interest; avoiding descriptions or manipulative influence tactics, and avoiding the use of high pressure.

Critics have raised questions on a universally positive effect of customer orientation. Frambach et al (2016), for instance, note that previous studies have suggested that customer orientation may cause firms to focus too much on the customers and, as a result, overlook newly emerging customer needs and thus decrease their novelty and innovation which will further affect performance. That notwithstanding, many scholars propose that customer orientation is beneficial and forms the basis for a firm's survival; 
leading to brand loyalty and higher profits to the firm (Ziggers \& Henseler, 2016; Maurya et al., 2015; Rodriguez et al., 2014). Thus, with respect to NTE firms in Ghana, it is proposed that:

$P$ 3: The degree of customer orientation positively influences the customer-based reputation of NTE firms.

\subsection{Reliability and Financial Strength of Company}

Reliable and financially strong company, as one of the dimensions of customer-based corporate reputation, is about the customer's perception of the company in terms of its competitiveness, profitability and growth prospects (Fombrun et al., 2015; Shahsavari \& Faryabi, 2013; Bartikowski \& Walsh, 2011). Walsh et al (2009) posit that the construct measures the customers' expectation that the firm uses financial resources so judiciously that investors would want to invest in it. Studies have indicated that reliable and financially strong firms outperform their competitors, recognize and take advantage of market opportunities, and have strong prospects for future growth (Bartikowski \& Walsh, 2011).

Thus, the key attributes of a reliable and financially strong firm are high profitability, good financial result, high growth prospect (Fombrun et al., 2015), outperforming competitors, taking advantage of market opportunities (Bartikowski \& Walsh, 2011), and high customer demand (Bohm et al., 2017). All manner of firms - large, medium, small or young - need to be financially strong I order to remain in business (Katsikeas et al., 2016). Research shows that financially distressed firms are neither able to pay preferred stock shareholders and suppliers nor bills that are overdrawn, they have too much debt to pay, violate conditions of payment with creditors (Geng et al., 2014), treat employees unfairly and are unable to recruit talented staff (Brown \& Matsa, 2015).

Literature shows that effective application of good stakeholder management practices is what a firm needs to achieve a strong financial performance (Bohm et al., 2017). Scholars have also found a relationship between corporate reputation and financial performance. Tomak (2014) observes that financial performance improves a firm's corporate reputation. Siano, Kitchen and Confetto (2010) believe that "both financial resources and reputational capital are managed under same basic principles" (pp 69). Hence, a hypothesis is developed as:

$H$ 4: The customers' perception of financial strength of NTE firms in Ghana positively influences the reputation of the firms.

\subsection{Corporate Social Responsibility}

The corporate social responsibility (CSR) dimension of customer-based corporate reputation implies the customers' perception of how the firm sees and acts towards the environment and the society (Shahsavari \& Faryabi, 2013) and whether the firm supports good causes (Bartikowski \& Walsh, 2011). Customers expect the firm to, apart from the profit-motive, act in a moral manner towards the employees and society and perform humanitarian responsibilities (Khan et al., 2013).

Dlamini (2016) identifies three dimensions of CSR, namely economic, social and environmental, and describes the economic dimension as the ethical practices such as good corporate governance, prevention of bribery and corruption, consumer protection, and ethical investments which promote the financial viability of the firm (Khan et al., 2013). The social dimension of CSR, according to Dlamini (2016), relate to the firm's obligation for the well-being of workers and the community; while environmental dimension describes the measures taken by the firm to maintain a clean and safe environment. Khan et al. (2013) also have internal and external constituencies of CSR and while the former relates to practices within the firm; the latter involves management of natural resources used in the production process.

Arikan et al, (2016) observe that CSR has a strong impact on consumer citizenship, employee satisfaction and emotional attachment, investor loyalty, customer satisfaction, trust and loyalty, and attracting and maintaining employees. Furthermore, CSR enables firms to ward off government regulations and interventions, and increase profitability by solving certain problems of the community (Khan et al., 2013).

Corporate reputation can be built through CSR since the practice makes firms become well known to the public (Dell'Atti \& Iannuzzi, 2016; King \& McDonnell, 2015). According to Dell'Atti and Iannuzzi 
(2016), CSR protects the value of corporate reputation and serves as insurance to firms. King and McDonnell (2015) revealed that investors seem to prefer high reputation firms because they are better able to deal with the consequences of boycotts than firms with weaker reputation. Thus it is proposed that:

P5: The CSR practices of NTE firms will have a positive impact on the corporate reputation of the firms.

\subsection{Customer Loyalty}

Customer loyalty is the "desired end of all marketing activity; the attitudes and behaviors" developed by customers towards a firm that make them become attached to the firm (Watson, Beck, Henderson \& Palmatier, 2015:2). According to Agarwal, Chaurasia and Negi (2012), customer loyalty exists when a person regularly patronizes a particular product, service, store or organization that he or she knows, likes and trusts. Hence, a loyal customer repeats purchases, increases in purchase value and volume over time and engages in advocacy (Agarwal et al., 2012).

It has been established in the literature that good corporate reputation promotes customer loyalty (Nyadzayo \& Khajehzadeh, 2016; Watson et al., 2015; Gorondutse, Hilman \& Nasidi, 2014). A group of theorists believe that a firm's reputation can be measured by the buying behavior of customers (Gorondutse et al., 2014; Shahsavani \& Faryebi, 2013); and that when their perceptions on corporate reputation are favorable, customer loyalty is higher. Customers are inclined to consume products from companies that have good reputation, since a good corporate reputation is said to reduce customers' perceived risk; thus increasing their desire to continue doing business with such a firm (Indradevi \& Laili, 2016).

In light of the above, and with respect to the NTE firms in Ghana, it can be proposed that:

P 6: Customer-based corporate reputation has a positive impact on customer loyalty.

The above research propositions on corporate reputation may be depicted as a conceptual frame work reflected in Figure 1.

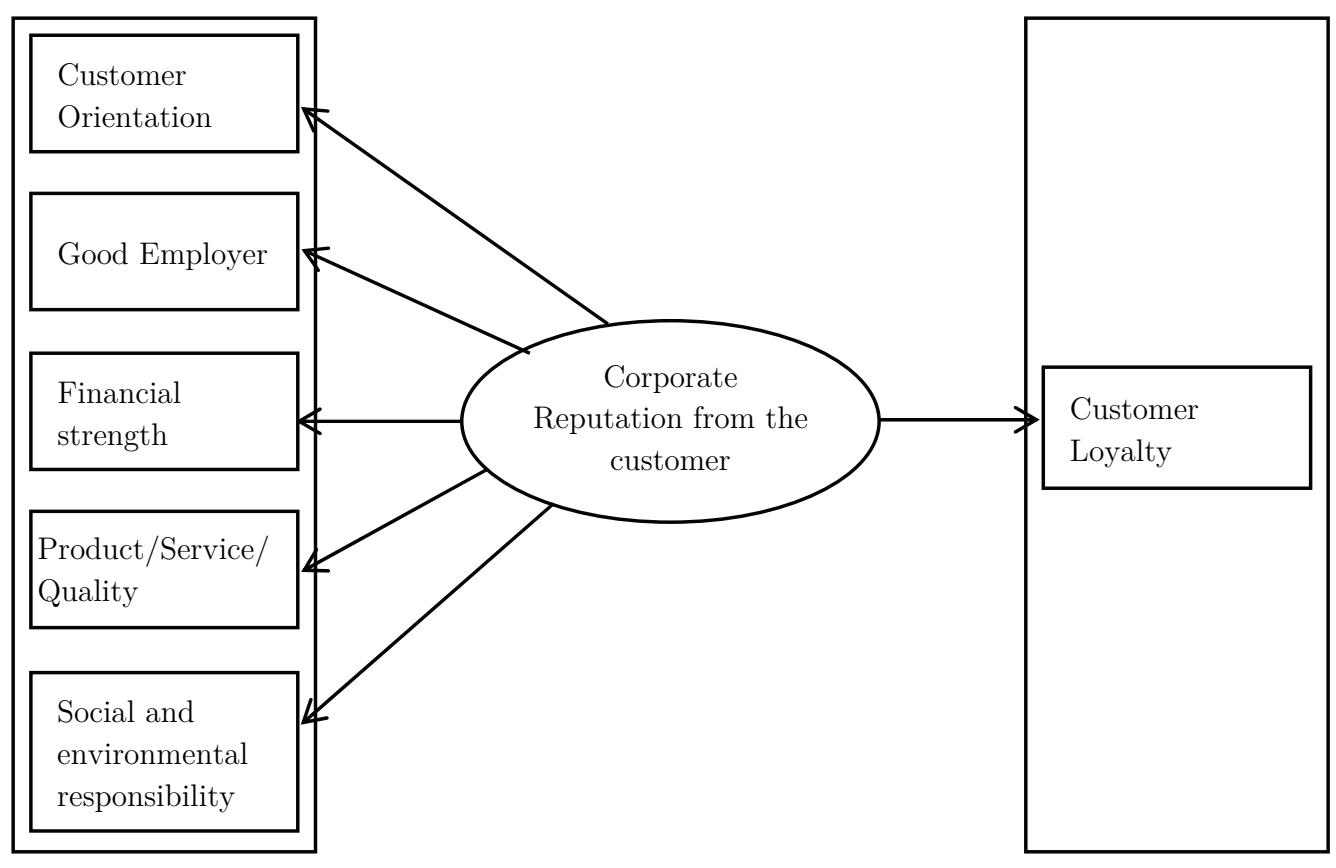

Figure 1. Conceptual Research Framework 


\section{Conclusions and Recommendations}

From a critical review of the literature, it became apparent that the reputation of NTE firms is crucial to their performance, because corporate reputation is found to one of the most important drivers of a firm's performance. Due to globalization, the marketing landscape has become more complex and competitive, since companies across the globe are offering a variety of products at competitive prices. The argument put forward is that by offering good quality products, thus satisfying the expectations of customers, the reputation of a firm would be enhanced. Furthermore, it may be concluded that by measuring corporate reputation, it is possible to evaluate the overall perspective including that of internal and external stakeholders, or to assess the perception of specific stakeholder groups, since different stakeholders have different perceptions about a firm as a result of their expectations of the firm. It is also possible, in measuring corporate reputation, to evaluate an overall perspective including internal and external stakeholders, or to assess the perception of specific stakeholder groups, since different stakeholders have different perceptions about a firm as a result of their expectations of the firm.

The conceptual paper has highlighted the need to conduct an empirical investigation of the customerbased dimensions of the corporate reputation of NTE firms in Ghana and the study should address inter-alia, the following objectives:

- Establish whether adopting customer-orientation in NTE business is effective in enhancing the firm's reputation.

- Assess the effects of good employer approach on building corporate reputation of NTE firms.

- Determine whether a firm's financial strength has an effect on its reputation.

- Assess the impact of product quality on the reputation of NTE firms in Ghana.

- Investigate the role of social and environmental responsibilities on building corporate reputation of NTE firms.

- Evaluate the implications of corporate reputation of NTE firms on customer loyalty.

Such a study will contribute to the creation of new knowledge on the corporate reputation of small firms and firms that engage in the exporting non-traditional products. The researchers consider the reputation of NTE firms as being crucial to their performance, because corporate reputation is found to one of the most important drivers of a firm's performance. Thus, the results of research will therefore go a long way to assist NTE firms in adopting effective reputation building strategies.

The threats of the banning of certain agricultural products exported from Ghana by EU consumers, was a disturbing phenomenon which impacted negatively on the export sector. Through this research, consumers' judgments on the products are assessed and suggestions made on how to build the reputation of NTE firms, which in turn, will boost the export of non-traditional products from Ghana.

The research stresses the need for the NTE firms to offer high quality products that meet customer expectations in the global market. It further highlights the role of leadership on a firm's reputation and the impact of the firms' reputation on customer loyalty. The recommendations informed by empirical findings may be capable of serving to avert the perennial threats of being banned by Ghana's trading partners.

\section{References}

1. Agarwal, V., Chaurasia, A., \& Negi, P. (2012). Business profitability through customer loyalty and satisfaction in India with special reference to Dehradun (Uttarakhand). International Journal of Marketing and Technology, 2(9), 135-143.

2. Agyei-Sasu, F., Anaman, K.A., \& Egyir, I.S. (2011). Using horticultural export industry as vehicle for growth. Journal of International Marketing and Exporting, 16, 42-56.

3. Ali, R., Lynch, R., Melewar, T.C., \& Jin, Z. (2015). The moderating influences on the relationship of corporate reputation with its antecedents and consequences: A meta-analytic review. Journal of Business Research, 68, 1105-1117.

4. Almacik, E., Almacik, U., Erat, S., \& Akein, K. (2014). Attracting talented employees to the company: Do we need different employer branding strategies in different cultures? Procedia - Social and Behavioral Sciences, 150, 336-175. 
5. Arikan, E., Knafur, D; Maden, C., \& Telci, E. (2016). Investigating the mediating role of corporate reputation on the relationship between corporate social responsibility and multiple stakeholder outcomes. Quality and quantity, 50(1), 129-149.

6. Artopoulos, A., Friel, D., \& Hallak, J.C. (2013). Export emergence of differential goods from developing countries: Export pioneers and business practices in Argentina. Journal of Development Economics, 105, 19-35.

7. Bartikowski, B., \& Walsh, G. (2011). Investigating mediators between corporate reputation and customer citizenship behaviors. Journal of Business Research, 64, 39-44.

8. Bohm, E., Eggert, A., \& Thiesbrummel, C. (2017). Service satisfaction: A viable option for manufacturing companies with deteriorating financial performance? Industrial Marketing Management, 60, 101-111.

9. Brown, J. \& Matsa D.A. (2015). Boarding a sinking ship? An investigation of job applications to addressed firms. Journal of Finance, 71(2), 507-550.

10. Christaensen, L., \& Devarajan, S. (2013). Making the most of Africa's growth. Current history, 112 (754), 181.

11. Dabirian, A., Kietzmann, J., \& Diba, H. (2016). A great place to work!? Understanding crowd sourced employer branding. Business horizons, 1-10

12. Dell'Atti, S., \& Iannuzzi, A.P. (2016). Reputation, reputation crisis and corporate social responsibility of banks: Measurement and relationships. In Dell'Atti, S; Trotta, A. (eds), Managing reputation in the banking industry. Springer, Cham. 33-35.

13. Dlamini, B. (2016). The impact of corporate social responsibility on company profitability in Zimbabwe: A case of a listed Telecommunication company. International Journal of Social and Economic Inventions, 2(4), 9-16.

14. Duygun, A., Mentes, S.A., \& Kubas, A. (2014). The impacts of complaint satisfaction on corporate reputation: A study of banking sector. International Journal of Trade, Economics and Finance, 20(3), 377-395.

15. Evans, J.R. \& Lindsay, W.M. (2014). Managing for quality and performance excellence, $9^{\text {th }}$ Edition, Cengage Learning.

16. Frambach, R.T., Fiss, P.C., \& Ingenbleek, P.M.T. (2016). How important is customer orientation for firm performance? A fuzzy set analysis of orientations, strategies and environments. Journal of Business Research, 69, 1428-1436.

17. Fombrun, C.J., Ponzi, L.J., \& Newburry, W. (2015). Stakeholder tracking and analysis: The Reptrak system for measuring corporate reputation. Corporate Reputation Review, 18(1), 3-24.

18. Ghana Export Promotion Authority, (2015). Non-Traditional Export Sector Performance. Statistical Snap Shots, GEPA, Accra.

19. Ghana Export Promotion Authority, (2016). Non-Traditional Export Sector Performance. Statistical Snap Shots, GEPA, Accra.

20. Ghana News Digest, February 17, 2014.

21. Geng, R., Bose, I., \& Chen, X. (2014). Prediction of financial distress: An empirical study of listed Chinese companies using data mining. European Journal of Operational Research, 241, 236-247.

22. Gorondutse, A.H., Hilman, H., \& Nasidi, M. (2014). Relationship between reputation and customer loyalty on Nigerian Food and Beverages Industry: PLS approach. International Journal of Management and Business Research, 4(2), 125-136.

23. Grunwald, G. \& Hempelmann, B. (2010). Impacts on reputation for quality on perceptions of company responsibility and product-related dangers in times of product-recall and public complaints crisis: Results from an empirical investigation. Corporate Reputation Review, 13(4), 264-283.

24. Gul, R. (2014). The relationship between reputation, customer satisfaction, trust, and loyalty. Journal of Public Administration and Governance, 4(3), 368-387.

25. Hanzaee, K.H. \& Mirvaisi, M. (2011). Customer orientation of service employees: A case study of Iranian Islamic Banking (Based on COSE Model). International Journal of Marketing Studies, 3(4), 130-145.

26. Helm, S. (2011). Employees' awareness of their impact on corporate reputation. Journal of Business Research, $64,657-663$.

27. Hidayat, A., Mahdaria, S., Linando, J.A., \& Ishak, A. (2017). The impact of perceived quality and corporate reputation towards positive word of mouth: Trust as moderating variable. Science and Technology Index, 29(2), 395-398.

28. Indradevi, G. \& Laili, H.Z. (2016). Towards an understanding of customer-based corporate reputation and consumer citizenship behavior. A conceptual model.

29. Ingenhoff, D., Buhmann, A., White, C., Zhang, T., \& Kiousis, S. (2018). Reputation spillover: Corporate crisis' effects on country reputation. Journal of Communication Management, 22(1), 96-112. 
30. Jasra, J.M., Khan, M.A., Hunjra, A.I., Rehman, R.A.U., \& Azam, R.I. (2011). Determinants of business success of small and medium enterprises. International Journal of Business and Social Science, 2(20), 274-280.

31. Jung, N.Y. \& Seock, Y. (2016). The impact of corporate reputation on brand attitude and purchase intention. Fashion and Textiles, 3, 1-15.

32. Kalita, M., \& Nath, R. (2014). Determinants of users' satisfaction on selection of mobile handsets: The case of India. International Journal of Scientific Research in Education, 7(2), 141-155.

33. Kanto, D.S., de Run, E.C., \& Md Isa, A.H. (2015). The reputation quotient as a corporate reputation measurement in the Malaysian Banking sector: A confirmatory factor analysis. Procedia - Social and Behavioral Sciences, 219, 409-415.

34. Katsikeas, C.S., Morgan, N.A., Leonidou, L.C., \& Hult, G.T.M. (2016). Assessing performance outcomes in Marketing. Journal of Marketing, 80, 1-20.

35. Khan, M., Majid, A., Yasir, M., \& Arshad, M. (2013). Corporate social responsibility and corporate reputation: A case of cement industry in Pakistan. Interdisciplinary Journal of Contemporary Research Business, 5(1), 843857.

36. King, B.G., \& McDonnell, M.H. (2015). Good firms, good targets: The relationship among corporate social responsibility, reputation and activist targeting. In Corporate Social Responsibility in a Globalizing World, 430454. Cambridge University Press

37. Love, L.F., \& Singh, P. (2011). Workplace branding: Leveraging human resource management practices for competitive advantage through "Best Employer" surveys. Journal of Business Psychology, 26(2), 175-181.

38. Luo, X., \& Zheng, Q. (2018). How firm internationalization is recognized by outsiders: The response of financial analysts. Journal of Business Research, 90, 87-106.

39. Manjunatha, N., \& Kumar, R.J. (2016). A bibliographic research on export marketing - A strategic module for export performance. The International Journal for Business and Management, 4(3), 193-214.

40. Matuleviciene, M., \& Stravinskiene, J. (2015). The importance of stakeholders for corporate reputation. Engineering Economics, 26(1), 75-83.

41. Maurya, U.K., Mishra, P., Anand, S., \& Kumar, P. (2015). Corporate identity, customer orientation and performance of SMEs: Exploring the linkages. IBM Management Review, 27(3), 159-174.

42. Mokhtaran, M., \& Komeilian, B. (2016). Exploring the effect of customer orientation on Dana Insurance performance considering the intermediary role of customer relations and service quality management. International Review, 3-4, 51-61.

43. Nicolo, D. (2015). Towards a theory on corporate reputation and survival of young firms. Procedia - Economics and Finance, 22, 296-303.

44. Nyadzayo, M.W., \& Khajehzadeh, S. (2016). The antecedents of customer loyalty: A moderated mediation model of customer relationship management quality and brand image. Journal of Retailing and Customer Services, 30, 262-270.

45. Osei-Assibey, E. (2015). Export Promotion in Ghana. African Centre for Economic Transformation.

46. Raie, M., Khadivi, A., \& Khdaie, R. (2014). The effect of employees' customer orientation, customer satisfaction, and commitment on customer's sustainability. Arabian Journal of Business and Management Review, 4(1), 109121.

47. Shahsavari, A., \& Faryabi, M. (2013). The effect of customer-based corporate reputation on customers' citizenship behaviors in banking industry. Research Journal of Applied Sciences, Engineering and Technology, 6(20), 3740-3755.

48. Shamma, H., \& Hassan, S. (2013). Customer-driven benchmarking: Strategic approach towards a sustainable marketing performance. An International Journal, 20(3), 377-395.

49. Siano, A; Kitchen, P.J., \& Confetto, M.G. (2010). Financial resources and corporate reputation. Toward common management principles for managing corporate reputation. Corporate communications: An International Journal, 15(1), 68-82.

50. Singh, R., \& Koshy, A. (2012). A new conceptualization of salesperson's customer orientation: Propositions and assumptions. Marketing Intelligence and Planning, 30(1), 69-82.

51. Sontaite-Petkeviciene, M. (2014). Crisis management to avoid damage for corporate reputation: The case of retail chain crisis in the Baltic countries. Procedia - Social and Behavioral Sciences, 156, 452-457.

52. Suchanek, P., Richter, J., \& Kralova, M. (2015). Customer satisfaction, product quality and performance of companies. Review of Economic Perspectives, 14(4), 329-344.

53. Tomak, S. (2014). Corporate reputation and financial performance of firms in Turkey. Academic Review of Economics and Administrative Sciences, 7(1), 289-303. 
54. Wallace, M., Lings, I., Cameron, R., \& Sheldon, N. (2014). Attracting and retaining staff: The role of branding and industry image. Workforce Development, 19-36.

55. Walsh, G., Bartikowski, B., \& Beatty, S.E. (2014). Impact of corporate reputation of non-monetary and monetary outcomes: The role of commitment and service context risks. British Journal of Management, 25(2), 166-185.

56. Walsh, G., \& Beatty, S.E. (2007). Customer-based corporate reputation of a service firm: Scale development and validation. Journal of the Academy of Marketing Science, 35(1), 127-143.

57. Walsh, G., Mitchell, V.W. Jackson, P.R., \& Beatty, S.E. (2009). Examining the antecedents and consequences of corporate reputation: A customer perspective. British Journal of Management, 20(2), 187-203.

58. Ziggers, G.W., \& Hensler, J. (2016). The reinforcing effect of a firm's customer orientation and supply-base orientation on performance. Industrial Marketing Management, 52, 18-26.

59. Zouaghi, F., Sanchez-Garcia, M., \& Hirsch, S. (2017). What drives firm profitability? A multi-level approach to Spanish agri-food sector. Spanish Journal of Agricultural Research, 15(3), 1-15. 